\title{
İkinci Dünya Savaşı Sonrası Polonya Sinemasında Milliyetçi Muhafazakâr Bir Yönetmen: Andrzej Wajda
}

SÜLEYMAN SIDAL*

slymnsdl@hotmail.com

Özet: Bu çalışma Polonya sinemasının dünya çapında ün kazanmış yönetmenlerinden biri olan Andrzej Wajda’nın politik görüşlerini gözden geçirmeyi amaçlamaktadır. Çektiği filmlerle milliyetçi ve muhafazakâr bir tutum benimseyen Andrzej Wajda’nın bakışını anlamak için Danton, Ecinniler ve Katyn isimli filmleri incelenecektir. Wajda'nın politik duruşunu ortaya koyabilmek için önce milliyetçilik ve muhafazakârlık kavramları değerlendirilecek, ardindan Wajda'nın hayatı ve filmografisi üzerinde durulacaktır. Esas olarak Danton, Ecinniler ve Katyn filmleri ele alınacaktır. Çalışmanın temel tezi Andrzej Wajda’nın belli ölçüde aydınlanma değerlerini miras alan Nazizm ve sosyalizme karşı Polonya milliyetçisi ve muhafazakâr değerleri ön plana çıkaran bir yaklaşım ortaya koyduğu yönündedir.

Anahtar kelimeler: Andrzej Wajda, Polonya sineması, Milliyetçilik, Muhafazakârlık, Aydınlanma değerleri.

\section{Giriş}

İkinci Dünya Savaşı sonrasında Doğu Avrupa’nın SSCB’nin uydusu haline gelmesiyle Avrupa'da yeni bir dönem başlamıştır. Bolşeviklerin Ekim Devrimi’ni tüm dünyaya yayma isteği ile kapitalizmle girdiği mücadele İkinci Dünya Savaşı’nda kısa süreli bir ittifaktan sonra Avrupa’nın ikiye ayrılmasıyla sonuçlanmıştır. ${ }^{1}$

İki süper güç, iki farklı dünya tasarımına sahip taraf arasında kalan ülkeler, iki dünya savaşı boyunca da savaş alanı olmanın verdiği maddi manevi kayıplar yetmezmiş gibi savaş sonrasında da bu tarafların fiili hâkimiyet alanına girmişler ve onların istediği model çerçevesinde dönüştürülmeye çalışılmışlardır. Özellikle, Doğu Avrupa örneğinde olduğu gibi önce Nazi Almanya’sının saldırılarına maruz kalan, ardından Almanya ile Rusya arasındaki kanlı çatışmalarda hedef haline gelen, en sonunda da kazanan taraf olan Rusya’nın hâkimiyetine geçen ülkeler özellikle komünizmin bu ülkelerde yaygınlaştırılıp, yerleşik hale getirilmesi sürecinde ${ }^{2}$ ciddi baskılar, devlet terörü, sansür ve ideolojik bombardımana maruz kalmışlardır. Bunun yanı sıra kendisi de eski bir köylü ülkesi olan ve ağır sanayi hamleleriyle kalkınmayı kurtuluş

\footnotetext{
* Arş. Gör., Gazi Üniversitesi İİBF, Siyaset Bilimi ve Kamu Yönetimi Bölümü. Galatasaray Üniversitesi, Siyaset Bilimi Bölümü Doktora Öğrencisi.

1 Eric Hobsbawm, Kısa Yirminci Yüzyıl (1914-1991), çev., Yavuz Alogan (İstanbul: Sarmal Yayınları, 2003), s. 277-313.

2 Helena Flam, Mosaic of Fear: Poland and East Germany before 1989 (New York: Columbia University Press, 1998), s. 1-51.
} 
olarak gören SSCB’nin kalkınmanın yükünü bu ülkelere yüklemesiyle hammadde, insan kaynağı, emek gücü olarak da Sovyet baskısına maruz kalmışlardır. ${ }^{3}$

$\mathrm{Bu}$ ülkelerden biri olan Polonya'da savaş sonrası dönemde yetişen birkaç dünyaca ünlü yönetmenden biri olan Andrzej Wajda da kendi kuşağının acılarını, tecrübelerini, özlemlerini, inançlarını yansıtan filmler üretmiştir. SSCB’nin Polonya'da gerçekleştirmek istediği dönüşüme karşı en sert muhaliflerden biri olan Wajda, sinemayı Polonya halkının kendi hikâyesini anlatmak, onu bu şekilde komplolara, ülke üzerinde oynanan oyunlara karşı bilinçli kılmak, tarihsel hafızayı taze tutmak ve yaşanan acıların tekrarını engellemek amacıyla filmlerini çektiğini belirtmiştir. ${ }^{5}$

Bu kısa çalışmada, çok sayıda filmi bulunan Wajda’nın 1983 tarihli Danton, 1988 tarihli Ecinniler ve 2007 tarihli Katyn isimli filmleri incelenecek ve bu filmler üzerinden politik bir okuma yapılacaktır. Wajda’nın politik tutumunu anlamak açısından önemli göstergelere sahip bu filmlerde özellikle muhafazakârlığın tarihsel olarak ortaya çıkış sebeplerinden biri olan Fransız İhtilali’nin ve onun getirdiği Aydınlanma değerlerinin, daha sonra Aydınlanma geleneğini miras alan iki ideoloji olarak Faşizm ve Sosyalizmin Polonya düşünsel ve siyasal tarihi üzerindeki etkilerini görmek anlamlı ve mümkündür.

Bu bağlamda öncelikle muhafazakârlık ile milliyetçilik ilişkisi ve bu fikir akımlarının Aydınlanma değerleri ve sol fikirlerle olan etkileşimi tarihsel perspektiften ele alınacaktır. Ardından Wajda’nın hayat hikâyesi ve filmografisi incelenecek ve bahsi geçen üç film üzerinden Wajda’nın politik tutumu değerlendirilecektir.

Bu çalışmanın temel iddiası, Andrzej Wajda’nın filmlerinde SSCB'yi Polonya’nın milli bağımsızlığının önündeki en önemli engel olarak göstermesi ve Marksist-Leninist ideolojinin geleneğe, kiliseye, dine ve halkın adetlerine, yerleşik ahlak kurallarına olan müdahalesine karşı takındığı korumacı tutum nedeniyle milliyetçi-muhafazakâr bir yönetmen olarak nitelendirilebileceği yönündedir.

\section{Muhafazakârlık ve Milliyetçilik İlişkisi}

Muhafazakârlık, kadim bir düşünce tarzı, doğal bir durum, değişimler karşısında takınılan bir tutum hatta maddenin doğasında var olan evrensel bir olgu olarak görülebilirse de aslında politik bir ideoloji ya da öğreti olarak tarih sahnesine çıkışı oldukça yeni sayılabilir.

Muhafazakârlığın tarih sahnesine çıkışını 1789 Fransız İhtilali’ne dayandırmak mümkündür. İhtilalin getirdiği rasyonalite, eşitlik, özgürlük, insan hakları gibi kavramların yanı sıra yapılan devrime karşı büyük bir öfke ve nefret duyan özellikle İngiltere'de ve Fransa'da eski rejimin ayrıcalıklı sınıflarına mensup kişilerin düşün-

3 Mark Mazower, Karanlık Kıta, çev., Mehmet Moralı (İstanbul: Bilgi Üniversitesi Yayınları, 2003), s. 187-210, 255-263, 300-306 310-317.

4 Poland (1944-1964) (Warsaw: Poland Publishing House, 1964), s. 201.

5 Andrzej Wajda, Sinema ve Ben, çev., Füsun Ant (İstanbul: Afa Yayınları, 1993), s. 141-145. 
celeriyle gelişen muhafazakârlı̆̆ $1 n^{6}$ esas itibariyle kendine ait bir içeriğe sahip olduğunu söylemek mümkün değildir. Muhafazakârlık, daha çok devrimle, değişimle, yenilenmeyle birlikte gelen şeylere karşı negatif bir tepkinin ürünü olarak ortaya çıkmıştır. Bu anlamda muhafazakâr fikirlerin daha çok aydınlanmacı-liberal düşünceler, Fransız İhtilali’nin getirdikleri üzerinden kendini inşa ettiği söylenebilir. Bu sebeple muhafazakârlığın neye karşı olduğunu belirlemek görece kolayken neye taraf olduğunu belirlemek bir o kadar zor bir iştir. ${ }^{7}$

Bunun yanı sıra muhafazakârlığın da tıpkı diğer modern ideolojiler gibi durgun-durağan bir yapısı yoktur. Muhafazakârlık kendini, muhafaza etmek istediği geleneği, değerleri ve kurumları her çağa ve topluma göre değiştirmektedir. Dolayısıyla muhafazakârlık her ne kadar değişim karşısında bir değişmeme, direnme durumu olarak görülse de sürekli döneme, koşullara ve toplumlara göre değişim geçirmekte ve aslında sürekli kendini yenilemektedir. ${ }^{8}$

Derli toplu bir fikirsel yapısı, sınırları az çok çizilebilir bir doktrini, en önemlisi de belli bir ütopyası olmadığı için muhafazakârlığın bir ideoloji olup olmadığı tartışmalıdır. Fakat, bakıldığında muhafazakârlığın keskin çizgilere sahip olmaması sınırlarının tamamen belirsiz olduğu anlamına gelmemektedir. Kendini ideoloji olarak tanımlamaması veya ideolojiler üstü, apolitik bir düşünce üslubu olarak görmesi, muhafazakârlığın gerçekten böyle olduğu anlamına gelmemektedir. Ayrıca bir ütopyasının bulunmaması muhafazakârlığın “ideal” olarak tanımladığı bir toplum tasavvuruna sahip olmadığı şeklinde de yorumlanamamaktadır. Bu sebeple muhafazakârlığı, faşizm, sosyalizm veya liberalizm gibi sert bir ideoloji olarak tanımlamak mümkün değilse de yumuşak bir ideoloji olarak tanımlamak mümkündür. ${ }^{9}$

Muhafazakârlığın genel bir çerçevesini çizmek gerekirse, salt akla karşı aklın yanında vahiy ve sezgilere yer vermek, bireyden hareketle mekanik bir toplum tasavvuru yerine üyelerden, aileden, cemaatten hareketle organik bir toplum tasavvuru yaratmak, akıl yerine geleneğe, dine ve ahlak kaidelerine; birey yerine topluma, eşitlik yerine adalete, özgürlük yerine istikrara ve güvenliğe; demokrasi yerine kontrollü, dengeli bir yönetime; güçsüz devlet yerine otoriter fakat totaliter olmayan güçlü bir devlete önem verdikleri ifade edilebilir. ${ }^{10}$

Bunun dışında muhafazakârlığın ekonomiye, özel mülkiyete, vatan ve ulus kavramlarına bakışının zaman içinde değişime uğradığı söylenebilir. Klasik muhafazakârlık olarak adlandırabileceğimiz ve daha çok Avrupa'da eski rejimin ayrıcalıklı sınıfının imtiyazlarını yitirmemek için verdiği mücadeleyi meşrulaştırmaya çalışan düşüncelerin, genel olarak burjuva sınıfına, onun ulus, milliyetçilik, vatan gibi kavramlarına, çoğunlukla yaşadığı ve birer güç merkezi haline getirdiği şehirlere ve en önemlisi

6 Brian Girvin, The Right in the Twentieth Century: Conservatism and Democracy (London: Pinter Publishers, 1994), s. 13.

7 Aytekin Yılmaz, Çağdaşs Siyasal Akımlar (Ankara: Vadi Yayınları, 2003), s. 94.

8 F. J. C. Hearnshaw, Conservatism in England (New York: Howard Fertig Inc., 1967), s. 20.

9 Firat Mollaer, Armağan Öztürk, "Muhafazakâr İdeoloji ve Rasyonalite”, İ.Ü. Siyasal Bilgiler Dergisi, 35 (2006), s. 50.

10 Bkz. Bekir Berat Özipek, Muhafazakârlık: Akıl, Toplum, Siyaset (Ankara: Kadim Yayınları, 2005). 
elde ettiği parasal güçle alt üst ettiği mülkiyet yapısına sıcak bakması beklenmemelidir. ${ }^{11}$ Ancak zaman geçtikçe ve eski rejimin ve onun toplumsal yapısının yavaş yavaş ortadan kalkmasıyla muhafazakârların da değişmeye başladığı ve özellikle Avrupa’da sosyalist-komünist düşünce ve hareketlerin güç kazanmasıyla liberal fikirlerle kısmi bir uzlaşma yoluna gittiği görülmektedir. Çünkü muhafazakârlar, devrimci konumunu zamanla kaybedip savunmacı bir pozisyona geçen liberaller ile yapılacak bir ittifakın daha olanaklı olduğunu ve liberal değerlerin muhafazakârlara, sosyalist değerlerin sunacağından daha fazla yaşam alanı sağlayacağını tahmin etmişlerdir. ${ }^{12}$ Böylece muhafazakârlar, sınırlı değişim, serbest piyasa ekonomisi, liberal demokrasi gibi liberal değer ve kurumlarla uyumlaşma yoluna gitmişlerdir.

Muhafazakârların liberallerle uzlaştı̆̆ yeni dönemde, üzerinde durduğu toplum ve muhafazakârlık için iki önemli tehdit söz konusudur. Bunlardan birincisi dışsal olan komünizm/sosyalizm/enternasyonalizm tehdididir. İkincisi ise içsel bir tehdit olan liberal değerlerden mülhem müsamahakârlık ve hümanist değerlerdir. Muhafazakârlara göre birinci tehdit, güçlü bir devlet, sağlam bir ordu ve saldırgan, tavizsiz bir dış politikayla çözülebilir. Bu kapsamda güçlü devletin varlığı, güçlü bir orduya ve halkın gücüne doğrudan bağlıdır ve bu güç ancak halkın bir yandan askeri bütçe harcamalarını desteklerken bir yandan da içeride toplumsal istikrarı ve huzuru bozan muhalifleri, komünistleri, düşman rejimlerle çalışan işbirlikçileri engellemeleriyle mümkün olur. ${ }^{13}$

İkinci tehdit, muhafazakârlara göre liberal-aydınlanmacı düşüncelerden ve refah devleti uygulamalarından kaynaklanmaktadır ve Tanrı'nın yerine insanı koyan ve insanı tüm evrenin merkezine alan anlayışın yarattığı ahlaki çöküntüyle ve refah devletinin yarattığı asalak ruh haliyle ilişkilidir. Aydınlanma değerlerinin yarattığı kendini evrenin merkezine koyan ve adeta kendine tapan, bireyci, egoist ve ahlaki kaygılar gütmeyen insan tipi, muhafazakârlara göre bugünkü toplumsal çöküşün merkezinde yer almaktadır. ${ }^{14}$

Muhafazakârlara göre ise çözüm, ekonomik alanda insanları aylaklığa, tembelliğe alıştıran refah devletinin ve onun yarattı̆̆ gereksiz-hantal bürokrasinin ortadan kaldırılması, sosyal alanda ise hümanist-aydınlanmacı-modernist değerlerin yerini dinsel-geleneksel ve ailevi değerlerin almasıdır. Yani önerilen model ekonomik liberalizm ile kültürel muhafazakârllğın mezcedilmesidir. ${ }^{15}$

Bu muhafazakâr bakışın bugün ABD ve özellikle Avrupa'da milliyetçi akımlarla işbirliğine gittiğine, milli kimlik, din, gelenek, kurumlar gibi kavramları kullanarak bunların yabancılara karşı korunması gerektiğini dile getirdiğine sıklıkla şahit olun-

11 Girvin, a.g.e., s. $94-107$.

12 Bruce Pillbeam, Conservatism in Crisis? Anglo American Conservative Ideology after the Cold War (New York: Palgrave Macmillian, 2003), s. 18.

13 Charles. W. Dunn ve J. D. Woodard, American Conservatism From Burke to Bush: An Introduction (London: Madison Books, 1990), s. 9.

14 Irving Kristol, Autobiography of An Idea: Neo Conservatism, Selected Essays (New York: The Free Press, 1995), s. 365-366.

15 Helmut Dubiel, Yeni Muhafazakârlık Nedir?, çev., Erol Özbek (İstanbul: İletişim Yayınları, 1998), s. 13. 
maktadır. Bu bağlamda muhafazakârların çok kültürlülüğe, ulusal sınırların dışa açılmasına, göçmenlere ve göçmen işgücüne karşı şüpheci hatta düşmanca bir tavır geliştirdiği söylenebilir. Bu kapsamda Avrupa Birliği projesine de birçok ülkedeki muhafazakârın şüpheci baktığı ve Avrupadaki ulus-devlet sınırlarının kaldırılmasina ve "ortak pazar" temelinde Avrupa ekonomisinin ve toplumlarının bir araya gelmesine sıcak bakmadıkları görülmektedir.

\section{Wajda'nın Hayatı}

Andrzej Wajda, 6 Mart 1926'da Polonya Suwalki'de doğmuştur. ${ }^{16}$ Wajda’nın ailesi Szarow köyünden gelmektedir ve iyi eğitim almış insanlar olarak dikkati çekmektedir. Babası ve amcaları küçük yaşta iken Krakow’a göçen ailenin babası (Wajda’nın dedesi) çocuklarının iyi bir eğitim alması için çalışmıştır. Babası 16 yaşında (Birinci Dünya Savaşı sırasında görev yapan bir Polonyalı Özgürlük Birliği olan) orduya katılmış ve orada hızlı bir şekilde subaylığa kadar yükselmiştir. Amcalarından biri, İkinci Dünya Savaşı patlak verinceye kadar demiryollarında memurluk yapmış, diğer bir amcası Wajda’nın da Almanya işgali esnasında çalıştığı çilingir dükkânını açmış, en küçük amcası ise gelecek vaat eden bir çiftçi hakları savunucusu olarak erken yaşlarda hayatını kaybetmiştir.

Savaştan sonra, yapmak istediği şeyleri gerçekleştirmesi için Krakow Güzel Sanatlar Akademisi’ne girmesi gerektiğini düşünerek doğduğu yeri terk eden Wajda, Krakow’a gitmiştir. Sonra, film okulunun kurulmasıyla birlikte Lodz’a geçiş yapmıştır. Fakat tüm film yapma fikirlerinin doğduğu, tartışıldığ 1 ve nihai olarak hayata geçirildiği yer olan Varşova'ya gitmeye karar verince, Krakow'da fazla duramamış ve ona göre normal bir insanın yaşamak isteyeceği bir yer olan Varşova'ya gitmiştir. Daha sonra bir kez daha Krakow’a dönen Wajda, kendi hayatı için "Kaçmak benim hayatımın en büyük parçası olmuştur ve olduğum yerden kaçmak ve başka yerlere gidip kimsenin yapmadığı, denemediği, büyük işleri başarmak benim en büyük tutkum, hedefim olmuştur” diyerek bir anlamda geldiği köklere sahip çıkmış ama bir şeyleri aşmak için gitmenin, yeni yerler ve şeyler keşfetmenin gerekliliğini de ortaya koymuştur.

1903 yılında Krakow’a göç eden Wajda’nın babası ve amcaları 1930'larda tekrar Krakow'da yaşamaya başlamışlardır. Savaş ve Alman işgali boyunca evlerinin arkasındaki çilingir dükkânında çalışan aile üyelerinin yanında bir dönem ünlü yönetmen de çalışmış ve amcalarının yakın ilgi ve koruması sayesinde hayatta kalabildiği gerçeğini itiraf etmiştir. Amcalarının koruyucu ve yardımsever tutumunun ailenin önemli bir erdemi olduğunu belirten Wajda’ya göre, bu erdem sayesinde birçok Yahudi'yi de Alman zulmünden korumuşlardır.

Bu dönemde her gün ağır bir tempoyla gece geç saatlere kadar çalışan Wajda bir yandan da resim yapmaktadır. Ona göre hayatının bu evresi, yaşamını kol emeği ile sağlamak zorunda olduğu bu dönem, onun daha sonraları fikirsel anlamda güç kazanan işçi hareketini, hak mücadelesini ve işçi sınıfının üyelerini daha rahat anla- 
masına olanak tanımıştır.

Babası genç bir subay olan Wajda'nın annesi ise Ukraynalıların okuduğu bir okulda öğretmenlik yapmıştır. Ona göre, baba ve annesinin tipik entelektüel evlilik olan subay-öğretmen evliliği, kendisinin entelektüel dünyası geniş bir ailede yetişmesine olanak tanımıştır. Ayrıca birisi orduda askerleri eğitmek, onları denetlemek ve yönetmekte, bir diğeri ise okulda öğrencileri eğitip, yönlendirmekte olan anne ve babasının sayesinde genetik olarak kendisinde de insanları yönetmek-yönlendirmek konusunda bir yetenek ve isteğin doğmuş olabileceğini belirtmektedir.

O yılların Polonya’sında anne babası gibi toplumu yöneten-eğiten insanların her şeye rağmen sonuçta bunu kişisel çıkarlar için kullanmadığını belirten Wajda, toplumsal çıkarların, dayanışmanın, ortak yaşamanın öncelikli olduğu, başkası için kendini feda etmenin yüce bir erdem olduğu bir düşünsel yapının varlığını ifade ederken ansızın patlak veren savaşın her şeyi yok ettiği gibi tüm bu değerleri de ortadan kaldırdığını söyler.

Wajda henüz 13 yaşındayken, 1939'da patlak veren İkinci Dünya Savaşı ile birlikte aile düzeni ortadan kalkmıştır. Babası, 72. Piyade Alayı'nın komutanı olarak savaşmaya gitmiş ve bir daha eve dönememiştir. 40 yaşında hayatını kaybeden Wajda’nın babası Jakub, uzun süre ailesi tarafından bir gün geri döneceği umuduyla beklenmesine rağmen Katyn'de bir ormanda çok daha sonraları Ruslar tarafından yapıldığı kesinlik kazanacak toplu bir infazda başının arkasına tek el ateş edilerek öldürülmüş ve toplu mezarlardan birine gömülmüştür.

Savaşla birlikte kırsal bir ortamda çocukluğunu yaşadığını düşünen Wajda için çocukluk çağı trajik biçimde sona ermiş ve artık bir anlamda olgunlaşmasının, büyümesinin zamanı gelmiştir. Aile ortamının yok olmasıyla boşluk içine düşen Wajda, okul ve kiliseye sarılmış, Alman baskısının henüz sınırlı olarak hissedildiği Güzel Sanatlar Akademisi'ne kayıt yaptırmıştır. Ancak zamanla işgalin şiddetinin ve baskısının artmasıyla, Wajda'ya göre artık eğitim bir mesele olmaktan çıkmış, hayatta kalmanın tek yolu saklanmak ya da bir fabrikada çalışmak haline gelmiştir.

Güzel Sanatlar Akademisi, Wajda’nın okuduğu yıllarda Fransız post-empresyonistlerinin tarzına uygun resimler yapan Fransa'da eğitim almış profesörlerin etkisi altındadır. Wajda'ya göre bu durum ilginç bir çelişki yaratmaktaydı. Akademide yapılan çizimler, resimler, renkler, çiçekler, nü tablolar Fransız ruhunu tam anlamıyla yansıtırken, Polonya’ya dair bir şey ifade etmiyordu. Ona göre koşullar, hikâye, gerçeklik, her şey bambaşkaydı dışarıda. Dışarıda dumanı tüten krematoryumlar, tutuklamalar, yasaklamalar, ayaklanmalar yaşanırken onların bunu görmezden gelip, sessiz kalması mümkün olmamalıydı.

Tüm bu sebeplerden dolayı Wajda 1945-46 yıllarında Krakow'da Polonya Birleşik İşçi Partisi'ne üye olmuştur. Burada sosyalizm ve sosyal gerçekçilik gibi akımlarla tanışan Wajda, işçi, çiftçi, fabrika resimleri içeren bu akımları çekici bulmadığı gibi, bunu Sovyet sanat akımlarının taklit edilmesi ve bir anlamda bu yolla Polonya’nın zihinsel olarak "Sovyetleştirilmesi” olarak görmektedir. Bu nedenle Wajda, Polonyaya 
daha uygun, özgün bir akım yaratmak, aramak için üç yıl boyunca çalıştığı akademiden ayrılmış ve bir gazetede tesadüf eseri öğrenci aradığını okuduğu film okuluna başvurmak için yola çıkmıştır. ${ }^{17}$

Film okulu, Wajda için klasik manada bir okul olamamıştır. Ona göre tüm fikirler, yaratıcı tartışmalar, Krakow'daki hocalarından kendine düşünsel bir miras olarak kalırken, film okulu bir anlamda bunu tamamlayacak teknik bilgiyi sağlamıştır. Wajda, bu yıllarda resim yapmak konusunda kafası karışık hale gelirken, politik durumu anlama, anlatma ve bir film yaparak kitleleri yönlendirme fikrine daha fazla ilgi duyar hale gelmiştir. Wajda’ya göre film okulu ideolojik amaçlarla yüklü bir okuldu ve amacı savaş sonrası Polonyada komünist ideoloji doğrultusunda dönüşümü yüklenecek ve yönlendirecek enteljansiyayı yaratmakt1. ${ }^{18}$ Zaten burada ders veren hocaların neredeyse tamamı sol düşünceleri savundukları geçmişlere sahip ve mücadelenin sonunda kendi rollerini oynayacakları günün geldiğine inanan kişilerden oluşmaktaydı. Ama içlerinde farklı sanat akımlarına açık isimler de vardı ve Wajda, bunlardan biri olarak gördügü rektör Jerzy Toeplitz sayesinde Fransız Avangart sinemasıyla tanıştığını ve bunun ileride çektiği filmlerini önemli ölçüde etkilediğini itiraf etmektedir.

1950 yılıyla birlikte Wajda, akademiden etrafındaki arkadaşlarıyla birlikte bir öğrenci filmi yapmaya karar vermiştir. Film çekme deneyimiyle, zor yönleriyle tanışan Wajda, kendisine konu olarak Polonya'da inşaa edilen ilk sosyalist şehrin (Nowa Huta) hikâyesini alır. Krakow'un komünistlere karşı bilinen tutumu nedeniyle sosyalistlerin yeni bir dönüşüm sürecine önderlik edecek bir şehir yaratmak istemesi son derece doğaldı. Yeni bir ideoloji Wajda'ya göre Polonya'nın damarlarına enjekte edilmekteydi. Ve bunun Polonya'nın bünyesine uyup uymayacağı, onu savaş esnasında ve sonrasında yaşadığı travmalardan ve içine girdiği bitkisel hayattan uyandırıp uyandıramayacağı da henüz belli değildi. Wajda’ya göre komünistlerin yaptığı, ideolojik bombardıman eşliğinde politik bir dönüşüm gerçekleştirmekti ama hesaba katmadıkları kültür diye bir şey vardı ve kültür onların istedikleri gibi yıkıp yeniden şekil verebilecekleri bir şey değildi.

Wajda, bir sinemacı olarak SSCB dönemi boyunca yaşamış ve film çekmiş olmasına rağmen, daha da önemlisi Polonya'nın yakın bir gelecekte yeniden bağımsız bir ülke olacağına dair çok güçlü bir inanca sahip olmamasına rağmen komünist partiye ve onun uzantılarına her zaman için mesafeli durmuştur. Ona göre partiye yakınlaşmak, onun kontrolü altına girmekle eş anlamlıdır. Parti’nin ilkeleri, politikaları, sürdürdüğü belli bir çizgi vardır. Bir sanatçı partiye yakınlaşırsa onun politik çizgisini izlemek gibi bir ödevle yüklenmek zorunda kalmaktadır ki bu bir sanatçıyı tek yönlülüğe, sanatsal yaratıcılığını, düşünsel mirasını göz ardı etmesine yol açmaktadır; bu yüzden Wajda partiye katılmadığı gibi katılmayı hiçbir zaman düşünmediğini ortaya koymuştur. 1989'da duvarın yıkılmasını ve ardından Sovyet baskısının Polonya üzerinden kalkmasını hayretle ve mutlulukla izleyen Wajda, hayalini kurdukları özgür-

$17 \mathrm{http} / / /$ culture.pl/en/artist/andrzej-wajda, Erişim tarihi: 14.01.2015.

18 Maciel Karpinski, The Theatre of Andrzej Wajda, çev., Christina Paul (Cambridge: Cambridge University Press, 1989), s. 2. 
lüğün yavaş yavaş Polonya’ya yerleştiğini ve bunun sevindirici hatta onun kuşağ iç̧in hayal edilmesi zor bir durum olduğunu ifade etmiş ve savaş sonrasının Polonya'sında yetişen dünya çapında filmler yapabilen birkaç yönetmenden biri olarak film çekmeye devam etmiş ve Polonyalılara kendi tarihlerini, gerçeklerini, kültürlerini anlatarak onları bilinçlenmeye çağırmaya devam edeceğini ifade etmiştir. ${ }^{19}$

\section{Wajda'nın Filmleri}

Andrzej Wajda otuzun üzerinde film yönetmiştir; ${ }^{20}$ yönetmen koltuğunda olduğu ilk uzun metrajlı filmi olan Pokolenie (Generation-Nesil) 1955 yılında çekilmiştir. Film, Nazi işgali esnasında Polonyada yaşananları bir gencin bakış açısından anlatırken, Nazi işgali karşısında partizanların kahramanca çalışmasını ve direnişini gözler önüne sermekte ve partizanları ülkeyi Nazi işgalinden kurtardıktan sonra demokratik bir düzen kurmak isteyen kişiler olarak göstermektedir. ${ }^{21}$ Ancak daha sonra Wajda, bu durumun dönemin koşullarıyla ilgili olduğunu, SSCB hâkimiyetindeki Polonya hükümeti tarafından senaryoda böyle bir değişiklik yapılmasının şart koşulduğu aksi takdirde filmin izlenemeyeceğini söylemesiyle böyle bir şey yapılmasına razı olduğunu belirtmiştir.

Ardından 1957'de Kanal (Canal-Kanal) ve 1958'de Popiol i Diament (Ashes and Diamonds-Küller ve Elmaslar) çektiği filmlerle üçleme haline getirmiştir. Kanal filminde 1944 yılında Nazi işgaline karşı gerçekleştirilen Varşova direnişini konu alan yönetmen, konuya farklı bir açıdan yaklaşarak bir tür masal gibi başlayan hikâyenin sonunu umutsuz, kötü ve ölümle bitirerek kahramanlara saygı duymakla birlikte karamsar bir gelecek tasviri yapmıştır. Film aynı yıl Cannes film festivalinde gümüş palmiye ödülüyle ödüllendirilmiştir.

Popiol i Diament'te (Küller ve Elmaslar) ise Sovyet işgalinden hemen sonraki ilk günlerde direnişin liderlerinin komünist bir hükümet kurmak için SSCB ile işbirliğine giderken, diğerlerinin yaşadıkları ve düştükleri ikilemler anlatılmaktadır. Bu film, bir yönüyle Polonya’nın umut edilen iyi geleceğine, bir yönüyle de komünizmin bunu gerçekleştirmek için doğru yol olup olmadığına yönelik yönetmenin kafasındaki düşünceleri, ikilemleri, karışıklığı yansıtması açısından ilginç ve önemlidir. Film, 1959 yılında Venedik film festivalinde Fipresci ödülünün sahibi olmuştur.

Wajda 1959'da Lotna’yı (Speed-Hız) çekmiştir. Hızıyla ün salan bir yarış atının hikâyesini anlattığı filmde yine Alman işgaliyle alt üst olan Polonya'yı arka planda veren yönetmen bir yerde hızlı at (Lotna-speed horse) ile hızlı savaşı (Blitzkrieg-speed war) karşı karşıya getirmiş ve sonunda kazanan savaş olmuştur.

Daha sonraki yıllarda aşk ve komedi filmleri de (Niewinni czarodzieje/innocent sorcerers-masum büyücüler) yöneten Andrzej Wajda, savaşın yarattığı yıkım sonrasındaki sancılı toplumsal yapının yarattığı belirsizlik-umutsuzluk ve karamsar ruh

19 Bu konuyla ilgili olarak bkz: "Barbara Hollander’in Andrzej Wajda ile 80. doğum gününde yaptığ1 röportaj”, http://www.wajda.pl/en/wywiad80.html, Erişim tarihi: 04.05.2012.

20 Wajda’nın bugüne kadar çektiği tüm filmleri için bkz: "Films by Andrzej Wajda”, http://www.wajda.pl/en/ filmy.html, Erişim tarihi: 01.05.2012; http://worldcat.org/identities/lccn-n50-21372, Erişim tarihi: 01.05.2012. 21 Daniel Borden vd., Başvuru Kitapları: Film, çev., Yasin Kara (İstanbul: NTV Yayınları, 2011), s. 296. 
halinden yavaş yavaş sıyrılmış ve daha olumlu tavır alan, eğlenceli yapımlara da başarıyla imzasını atabilmiştir. Ancak bu çok uzun sürmemiş 1961 yılında çektiği ve bir Alman arkadaşını kaza sonucu öldüren ve 10 yıl hapisle cezalandırılan Yahudi bir gencin Varşova’nın bombalanmasıyla salınıp gettoya gönderilmesini konu edinen Samson filmiyle yeniden geri dönmüştür.

1970’ler Wajda için yaratıcılığı ve verimliliği açısından parlak bir dönem olmuş ve Wajda bu dönemde bazıları başyapıt mertebesine yükseltilen onun üzerinde filme imza atmıştır (Pilatus und andere-1972, Wessere-1973, Ziemina obeicana-1975, Człowiek z marmuru-1977, Dyrygent-1980). ${ }^{22}$ Özellikle, 1968 hareketiyle baş gösteren yeni toplumsal kargaşa ve artan politik muhalefet, Wajda için de yeniden bir umut olarak ufukta belirmiş ama yönetmen yine de filmlerinde temkinli olup fazla umutlu olmamaya özen göstermiştir. 1970 yılında çektiği ve Nazilerin toplama kamplarından birinde tutulan bir şair ile zeki bir kız arasındaki aşka, savaşa ve hayatta kalmaya dair bir konuya sahip olan Krajobraz po Bitwie (Landscape After the Battle-Savaştan sonra manzara) filmi de tipik olarak mutlu son sayılamayacak biçimde sona ermektedir.

1977 yapımı Człowiek z marmuru (Man of Marble-Mermer Adam) filmi de bir anlamda sarsılmaya başlayan SSCB'ye ve onun Polonyadaki politikalarına şiddetli bir tepki olarak gelişmiştir. Wajda, bu filmiyle Polonyada ortaya çıkan "Solidarnosc" Dayanışma Hareketi’ne desteğini belli etmektedir ve bu Polonya hükümetinin Wajda’nın yapım şirketinin faaliyetlerini yasaklamasıyla karşılık görmüştür. Film, antikomünist tutumuyla 1950’lerin Stalinist terörünü eleştirmek vasıtasıyla bugüne, yapılanlara karşı çıkışı simgelemektedir ancak yine de tepki bir çıkış yolunu beraberinde getirmemekte ve Wajda sadece eleştirmekle kendini sınırlamaktadır.

Ancak Wajda, tüm olanlara rağmen muhalif tavrından vazgeçmemekte ve 1983 y1lında Danton filmini çekmektedir. Bu filmde Fransız Devrimi'nin hemen ardından gelen kanlı terör dönemini konu eden yönetmen, Danton karakteri üzerinden devrimi sorgulamakta ve devrimi korumak adına gerçekleştirilen yaygın şiddet ve baskıyı sorunsallaştırmaktadır. Bu, bir anlamda SSCB'nin tüm Doğu Avrupa’ya özellikle kaynamaya başlayan Polonya’yı baskılamaya çalışmasına bir tür tepki olarak da görülebilmektedir.

1990’ların başında senatör olarak seçilen Andrzej Wajda, yeniden konusu İkinci Dünya Savaşı sırasında geçen savaş filmleri çekmeye devam etmiştir. Bu kapsamda çekilen 1993 yapımı Pierscionek z orlem w koronie (The Ring with a Crowned Eagle-Taçlı Kartal Yüzüğü) ve 1996 yapımı Wielki tydzien (Holy Week-Kutsal Hafta) filmleri Polonyảnın hem savaş sırasında ve sonrasında yaşadığı yıkım ve iki güçlü devlet arasında kalmanın verdiği eziklik hissi ile birlikte iki devletin de aslında birbirinden çok da farklı olmadığını veya ikisinin de Polonya için birinin diğerinden daha iyi olmadığını anlatmaktadır.

1997 yılında çektiği Panna Nikt (Miss Nobody-Bayan Hiç kimse) filmiyle Wajda, ko-

22 Borden vd., a.g.e., s. 304. 
münizm ve materyalizmin Polonya toplumunda yarattığını düşündüğü ahlaki zaafları dile getirmekte ve özellikle bu yeni değerler yapısının eskinin, geleneksel olanın, Polonya’nın kültürünün altını oyduğunu, onu bozduğunu düşünmekte ve materyalizme, komünizm sonrası gelişen toplumsal yaşama, ahlaki değerlere ciddi eleştiri getirmektedir.

1999 yılında çektiği Pan Tadeusz filmiyle ciddi bir gişe başarısı yakalayan yönetmen, bu filmindeki başarısını sinemanın yanı sıra tiyatro ile de ciddi biçimde uğraşmasına ve edebiyat uyarlamalarına filmografisinde önemli yer vermesine bağlamaktadır. Daha sonrasında televizyon için diziler de çeken Wajda 2000 yılında sinemaya yaptığı katkılardan dolayı Oscar Ödülü’ne layık görülmüştür. 2001 yılında kendi ismini taşıyan film yönetmenliği okulunu açan Wajda, 2006'da Berlin Uluslararası Film Festivali'nde Altın Ayı ödülünü almıştır. ${ }^{23}$

2008 yılında çektiği Katyn filmi yönetmenin kendisi için bir tür tarihsel yüzleşme olarak görülmüştür. Kendi öz babasının da aralarında bulunduğu Polonyalı subayların Almanya'yı destekledikleri gerekçesiyle SSCB ordusu tarafından Stalin'in emri doğrultusunda Katyn ormanlarında toplu olarak infaz edilişinin acı hikâyesini anlatan yönetmen bu filmiyle artık Avrupa Birliği üyesi olan ve Batı ile tam bütünleşme hedefi doğrultusunda ilerleyen bir Polonyada geçmişle hesaplaşmaya girmekte, hem Nazi Almanyası'nın hem de Stalin SSCB’sinin yarattığı korku-baskı-sansür ve şiddet sarmalının yıkılmasını buruk bir sevinçle karşılamakta ve Polonya’yı bir anlamda tetikte olmaya çağırmaktadır.

\section{Danton}

Wajda’nın 1983 yılında çektiği Danton ${ }^{24}$ filminin konusu ilginçtir. Film, 1794 yılında cumhuriyetin ikinci yılında Fransa’nın başkenti Paris’te geçmektedir. Fransız İhtilali gibi önemli bir tarihsel konuyu ele alan yönetmen, filmde Cumhuriyetin kuruluşunun ardından gelen Jakoben terör döneminin hemen başlangıcında ${ }^{25}$ devrimin en önemli karakterlerinden biri olan Danton'un Paris’e yeniden dönüşü ile başlar. Cumhuriyet kurulmuş, kral idam edilmiş ve artık yönetim bir komitenin ve halk meclisinin elindedir. Görünüşte meclis yetkili gibi gözükse de, asıl güç ve otorite sahibi komitenin kendisidir. Bu komitenin başında ünlü Robespierre ${ }^{26}$ vardır. Robespierre uzun bir hastalık döneminden sonra yeniden ayağa kalkmıştır. Hastalığının, filmde, fiziksel olduğu kadar ruhsal bazı sorunlardan kaynaklandığı gibi bir izlenim verilmektedir. Çünkü Robespierre'in devrimin gidişatı ile ilgili ciddi sıkıntıları, ikilemleri ve kafa karışıklıkları mevcuttur. Robespierre'e göre uğruna devrim yaptıkları, sistemi kökünden değiştirdikleri, yaşamalarının amacı olan ilkeler ile mevcut durum arasında hayli büyük bir farklılık oluşmuş durumdadır ve başta kendisi olmak üzere var olan bu farkı yok etme konusunda esaslı bir çözüm yolu bulabilmiş değillerdir. Ko-

23 http://www.filmreference.com/film/88/Andrzej-Wajda.html, Erişim tarihi: 05.05.2012.

24 Danton, 1983, Andrzej Wajda, Fransa-Polonya-Batı Almanya ortak yapımı, http://www.imdb.com/title/ tt0083789, Erişim tarihi: 05.05.2012.

25 Mieczyslaw Szporer, “Andrzej Wajda’s Reign of Terror: Danton's Polish Ambiance”, Film Quarterly, 37/II (1984), s. 27-33.

26 Server Tanilli, Fransız Devriminden Portreler (İstanbul: Adam Yayınları, 2003), s. 51-55. 
mite, öyle ya da böyle işleyen bir devlet ve toplum yapısını aniden yıkmanın vermiş olduğu karmaşa ve kargaşa arasında düzeni yeniden kurup sürdürme ile otoritesini pekiştirme arasında gidip gelen, bundan sonrası için biraz da karamsar biçimde ne yapılması gerektiği konusunda çıkar bir yol aramaktadır. Bir yandan, içeride sermaye sahibi kişiler, mallarına ve servetlerine el konulacağı gerekçesiyle; eski kralcılar yok olan ayrıcalıklarını yeniden kazanmak hevesiyle, yabancı ülkeler de bu yeni düzenin bir devrim dalgası yaratarak ülkelerine sıçramasının yarattığı endişe ile dört bir yandan Fransa üzerine baskı kurmaya çalışırken, tam da böyle kaotik bir ortamda, "şanlı" devrimci Danton bir gece yarısı çıkagelir. Adeta bir kurtarıcı, bir fatih edasıyla onu karşılayanları selamlar ve gülümserken, komiteye Danton’un komitenin iktidarını yıkmak için gizli bir darbe yapacağı söylentisi ulaşır; bardaktaki son damla da taşmış olur. Robespierre'in bazı eski dostlara eski günlerin hatırına onlara yapacağı "bize katılın" çağrılarının da teker teker reddedilmesiyle ölüm fermanları yazılmış olur. Sarsıntılar yaşayan bir devrim, hayatta kalmak için içgüdüsel bir şekilde kendi kendini korumak ve düşmanlarını yok etmek için harekete geçer ve kahraman-kurtarıcı Danton ve "muhalif” arkadaşlarının sonu tüm haklılıklarına rağmen giyotin olur.

Wajda’nın Fransız İhtilali ile ilgili bir film yapması hem kendi düşünsel yapısı için hem de yaşadığı dönemde Polonyảnın içinde bulunduğu koşullarla oldukça yakından ilintilidir. Muhafazakâr bir kavrayışa sahip olduğunu düşündüğüm yönetmen için Fransız İhtilali semboliktir. Çünkü muhafazakârlı̆̆ın bir düşünce üslubu ya da modern bir ideoloji olarak ortaya çıktığı dönem tam da Avrupa'da Fransız İhtilalinnin patlak verip ardından dalga dalga kıtaya yayılmaya başladığı dönemdir. $\mathrm{Mu}$ hafazakârlık, tam da değişim, dönüşüm, kargaşa dönemlerinin yükselişe geçtiği bir zaman diliminde ortaya çıkarken, kendini bu değişim sürecine karşı korunması gereken belli bazı kavramlar-değerler üreterek, bunları bir anlamda kendileri için korunaklı adacıklar-kurtarılmış bölgeler haline getirerek anlamlı hale getirmektedir.

Muhafazakârlık, dönemin koşullarında eski düzenin (status quo ante) savunmasına dayalı olarak, aristokratik ve kralcı değerlerin, geleneksel toplum yapısının ve kurumlarının yanı sıra sınıfsal olarak bazı çıkarların savunusu üzerinden şekillenmiş ve en büyük düşman aydınlanma felsefesi ve onun siyasal alanda sonucu olan Fransız İhtilali olmuştur. ${ }^{27}$ Aydınlanma aklına ve onun saf-bağımsız akıl anlayışına, toplum karşısında bireye verilen önem ve öncelikle bireyin kendisini dolayısıyla toplumu değiştirecek potansiyele sahip olduğu yönündeki inanca karşı çıkan muhafazakârlar, eşitsizlikleri ve sınıflar arası farklılıkları kutsayan bir anlayışla, geleneksel kurum ve yapıların denetimi altında işbölümüne dayalı organik bir toplum anlayışını benimsemişlerdir. Var olan düzeni, ataların bilgisine sahip, zamanın tecrübesinden geçmiş, olabilecek en iyi düzen şeklinde gören muhafazakârlar, değişime, hele hele köklü devrimlere şiddetle karşı çıkarlar ve insanın kusurlu-eksik bir varlık olarak sağlıklı bir değişimi, dönüşümü tek başına (geleneğin-kurumların veya dinin rehberliği olmaksızın) gerçekleştiremeyeceğini savunarak devrimleri bir toplumun başına gele-

27 Andrew Heywood, Political Ideologies (New York: Palgrave, 1998), s. 66. 
bilecek en kötü durum olarak görürler. ${ }^{28}$

Danton filminde, komitenin içinde bulunduğu çaresizlik durumu, komite üyelerinin ne yapacağını bilmez hal ve tavrı manidardır. Eski düzeni yıkma cüretinde bulunmuşlardır. Bu sebeple eski düzenin yol gösterici kurumları arasında yer alan aristokratlar-din adamları, gelenekler de yok edilmiş olduğu için önlerinde onlar için hiçbir yol gösterici kalmamıştır. Ayrıca gelenek, kurumlar, en önemlisi dini-ahlaki kurallar toplum içinde ilahi adaleti tesis ettiği için, bunların zaafa uğratılması nedeniyledir ki komite içeride toplumu nasıl yöneteceğine karar veremezken, dışarıda insanlar açlık-yoksulluk içinde ekmek kuyruğunda beklemektedir. Düzen bozulmuştur bir kere; kaynağı kutsal görülen iktidar-otorite kutsal olmayan kişilerin elindedir.

Otorite, muhafazakâr söyleme göre, kral için Tanrı’nın ilahi emridir ve kral Tanrı’ya karşı sorumludur. Bu kendisini adaletli yapmakta; Tanrı'dan aldığı otorite onu hiçbir şekilde yozlaştırmamakta, bozmamaktadır. Bir anlamda kendisi seçilmiş kişi olarak görülmektedir; fakat Fransảnın başındaki komite üyeleri, yani avukat-doktor-polis-marangoz gibi kişiler sıradan, bayağı kişilerdir ve Tanrı tarafından seçilmedikleri gibi, ne ona ne de topluma karşı bir sorumluluk duygusu taşımaktadırlar. Bu yüzden adaletli olamadıkları gibi, iddia ettikleri gibi eşitlikçi de olamamaktadırlar; güç doğal olarak onları yozlaştırmaktadır. Bu sebeple, filmde, Danton geldiğinde başta Robespierre olmak üzere komite üyeleri iktidarlarının, yönetme güçlerinin, ayrıcalıklarının ellerinden gideceği korkusuyla onu gözlerini kırpmadan öldürebilmişlerdir. Filmde, Wajdảnın komite üyelerini, şizofrenik, megaloman, güce tapan, şiddete-öldürmeye eğilimli uçuk-merhametsiz-yarı deli olarak seyirciye sunması muhafazakârların devrimcilere bakışını yansıtması açısından oldukça ilginçtir. Bunun yanında komite üyelerinden birinin yüzünün makyajlı olması 1970'lerle yükselişe geçen yeni muhafazakârlığın cinsel tercihlere karşı homofobik ruh halini yansıtması açısından isabetli bir tasvir olmuştur.

Filmin iki ana karakteri Robespierre ile Danton arasındaki kavga aslında son derece semboliktir. Robespierre'in filmde, Danton'un karşı devrim hazırlı̆̆ı içindeki hain burjuvalarla işbirliği yapabileceğini söylemesi onu bir anda tarihsel gerçekliği de zorlayan bir biçimde liberalizmin karşısına koymakta ve halkın, tüm sınıfların eşitliği için çalıştığını ifade etmesi onu toplumcu (sosyalist) bir çerçeveye oturtmamıza olanak tanımaktadır. Buna karşın burjuvalarla işbirliği yapma potansiyeline sahip, şatafatlı bir evi olan, yemeğin-içkinin ve kadının güzelinden anladığı iddiasındaki Danton kolaylıkla Robespierre'in karşıtı haline gelmektedir. Danton'un devrimci kişiliği, Fransız devriminde oynadığı rol, kralın idamı için verdiği mücadele, kendisinin de ilahi takdirin bir sonucu olarak yargılanarak giyotine gönderildiği devrim mahkemesini kurması ${ }^{29}$ çok üstün körü verilmekte ve Danton kasıtlı biçimde Robespierre'in karşısına liberal-muhafazakâr değerlere sahip, halkçı-iyiliksever bir tip olarak oturtulmaktadır. Danton'un film boyunca şiddete-darbeye-karşı devrime ilkeli bir biçimde karşı çıkışı bu açıdan şaşırtıcı olmadığı gibi, halkın kışkırtılmasına,

28 Özipek, a.g.e., s. 31-42.

29 Tanilli, a.g.e., s. 108-110. 
kitlelerin seferber edilmesine karşı korkuyla karşı koyuşu ve her zaman sağduyuyu-mantığı-makul olanı ileri sürmesi tipik bir muhafazakâr profili yansıtmaktadır.

Muhafazakârların devrimler karşısında tarihsel devamlılı̆̆ liği ön plana alan tarihsel bir anlayışı savunması ile yakından bağlantılı olarak, filmde devrimin ardından çok fazla bir şeyin değişmediği görülmektedir. Devrimden önce sosyal sınıflar vardı ve bu sosyal sınıflar arasında hukuki-ekonomik ve toplumsal ciddi eşitsizlikler-farklılıklar mevcuttu. Fakat devrimden sonra da bu durum değişmemiş, neredeyse aynı kalmıştır. Üyeleri kısmen değişmiş olsa da sınıflar kalmıştır ve onların adına yapıldığı iddia edilen devrimin varlığına rağmen kitleler sokaklarda, hizbe hanlarda hatta hapishanelerde uyumakta, ekmek kuyruğunda sira beklemekte, polisten şiddet görmekte, sorgusuz sualsiz tutuklanmakta, çok kolay şekilde idam edilmekte fakat buna karşın üst sınıflar binbir çeşit şarap-yemek yiyip içebilmekte, her türlü ürünü temin edebilmekte, istedikleri takdirde her türlü ayrıcalıktan yararlanabilmektedir. Yani devrim hiçbir şeyi değiştirmemiş, kitleler aslında belli gruplar tarafından tahrik edilmiş ve kendi çıkarları için kullanılmıştır.

Muhafazakârların devrimcileri hayalci olarak nitelemesi boşuna değildir. Onların hayatı teorik modellerle kavradıkları ve toplumu bu teorik modellere uydurmaya çalıştıkları ve uymadığı zaman toplumu olmadıkları bir şeye zorladıkları muhafazakârlar tarafından geliştirilen bir eleştiridir. ${ }^{30}$ Danton'un bu minvalde Robespierre’e karşı çektiği nutukta insanları olmadıkları şeyler-masal kahramanı olarak görmekten, insanları kendi hayallerinde canlandırdıkları cennetvari bir düzene uymadıkları için suçlamaktan, insanları kendi hayallerine uygun olarak değişmeleri için zorlamaktan vazgeçmelerini ögüutlemesi tam da bu noktaya işaret etmektedir. Bu yüzden Danton bir muhafazakâr gibi, aslında aydınlanmanın düşünsel yapısını halkçı olmak bir yana halkı tanımamakla, cumhuriyetçileri ne isteyip istemediklerini bilmemekle, halk adına bu sebeple konuşmaya hakları olmamakla suçlamaktadır. Çünkü muhafazakârlara göre halk devrim istiyor değildir. Onun istediği güven içinde yaşamaktır. Varlığını korumak, çoğalmak, iyi beslenmektir. Bu yüzden Robespierre’e Danton hiddetle "bir kadınla yatmamış gibi duruyorsun" demekte, ona uzattığı çeşit çeşit yemeklerin tadına dahi bakmadığı için hepsini yere dökmektedir. Yine aynı Danton, darbe ya da iktidar isteyip istemediğini soranlara "sadece kafamı dinlemek, sakince yaşamak istiyorum” diye cevap verirken muhafazakâr, dingin, sessiz ve belki biraz da taşralı bir hayata olan özlemini dile getirmektedir.

Yönetmenin, kişileri izleyicilerin gözünde iyi ve kötü olarak göstermek-koşullandırmak istemesinin bir sonucu olarak Danton güler yüzlü, zevkli, en kötü anda bile mantıklı düşünebilen, espri yapabilen, yemek ve yaşam hakkında kültür ve tarz sahibi, karizmatik, güçlü, erkeksi yönleriyle ön plana çıkarken Robespierre, çirkin, asık suratlı, hasta görünümlü, hiç gülmeyen, yönetmek dışında hayata dair hiçbir zevki-ilgisi olmayan, tek yönlü ve bununla birlikte kısa boylu, çelimsiz, kadınsı ve cinsel açıdan iktidarsız gibi resmedilmektedir.

Muhafazakârların, Fransız İhtilali’ne karşı güç birliği yaratması ve bir süre son- 
ra Avrupa'da devrimlerin ardından karşı devrimlerin de başlamasına koşut olarak muhafazakârlarda ilahi adaletin bir gün yerini bulacağı kanısı oldukça yerleşiktir. Bunun Hıristiyanlıktaki İsa’nın geri gelip yeryüzünde adaleti tesis edeceği bin yılc1 inanışların da etkisi vardır. Yani bu bir savaşsa, ilk savaş kaybedilmiş olsa bile bir gün mutlaka tersi gerçekleşecektir. Çünkü Tanrı muhafazakârların tarafındadır. Cumhuriyetçilerin tarafında olması da beklenmemelidir. Bu anlamda Danton'un ve beraberindeki 12 kişinin İsa ve 12 havarisinin bir temsili olması şaşırtıcı değildir. Danton'un iyilik havarisi, bir tür peygamber gibi, bütün film boyunca resmedilmesi ve Yahudilerin İsa'yı haksız yere tutuklayıp, mahkemelerde yargılamaları ve sonunda Golgotha tepesinde çarmiha germeleri gibi Danton da esaslı sözler söyler ve sonunda boynunu giyotine uzatır. Giderken Robespierre'e söylediği "benim ardımdan senin de sonun gelecek, tarih seni unutacak ama beni hatırlayacak" demesi aslında İsa'nın onu Yahudilere ihbar eden ve ölümüne sebep olan Yahuda İşkaryot’a söylediklerine oldukça benzemektedir. Zaten Yahuda da bir süre sonra kendini öldürecektir. Tipkı Robespierre'in St. Just’a "kafasına bir kurşun sıkmak" istediğini söylemesi gibi.

Sonuçta, filmin seyircinin önüne koyduğu anafikir, tüm yapılan kötülüklere rağmen, tüm kıyımlara rağmen zamanı geldiğinde -hesap günü- kazanan Robespierre -Yahuda, kötülük, ihanet- değil Danton -İsa, iyilik, dostluk- olacaktır şeklinde özetlenebilir.

\section{Ecinniler}

1988 yılında çektiği Ecinniler (Les Possédés) filmi ${ }^{31}$, Wajda’nın politik duruşu açısından incelenmesi gereken bir başka önemli yapıttır. Fyodor Dostoyevski'nin aynı adlı romanından uyarlama olan bu filmde 1870 yılında Rusya’da küçük bir kasabada bir grup gencin var olan çarlık düzenini şiddet kullanarak zorla devirme girişimleri anlatılmaktadır. Kimilerine göre Dostoyevski’nin bir kâhin gibi geleceği (Bolşevikleri) önceden tahmin ettiği bir roman olarak ele alınması gereken hikâyenin Wajda’nın elinde farklı amaçlarla yeniden kurgulandığına şüphe yoktur. Wajda’nın tam da Berlin Duvarı'nın yıkılmasına bir yıl kala çektiği film, aslında SSCB'nin hâkimiyetine karşı felsefi ve politik bir karşı çıkış şeklinde de okunabilmektedir.

Rusya’nın Bolşevik devrim öncesi toplumu, filmde aslında çürümeye yüz tutmuş, kurumlarıyla, yöneticileriyle olsun artık yıkılacağı içten içe kabul edilmiş ve toplumsal huzursuzluk ancak şiddetle kontrol altına alınabilecek noktaya değin varmış bir yer olarak tasvir edilmektedir. Öyle ki yöneticiler bile, eski düzenden umudunu kesmiş, yerine gelme ihtimali olan kişi ve gruplara yakın durmaya çalışarak konumlarını korumaya çalışmaktadırlar. Ancak bu düzeni değiştirme görevine talip olanların maddi ve manevi olarak bu ağır yükün altından kalkabilecekleri son derece şüpheli gözükmektedir. Zira filmdeki devrimci grup, birkaç gençten oluşan basit bir örgütlenme olarak görülmektedir. Tipkı Danton filmindeki komite gibi bu devrimci grup da son derece beceriksiz, yeteneksiz, hiçbir özelliğe ve karizmaya sahip olmayan kişilerden oluşmakta ve son derece bilgisiz, cahil; mantıklarından ziyade duygularıyla hareket eden, cesaretten çok korkaklık ve entrika çevirmeye yatkınlık gösteren, aklı bir karış

31 Les possédés, (1988), Andrzej Wajda, Fransa yapımı, http://www.imdb.com/title/tt0093765, Erişim tarihi: 01.05.2012. 
havada bir avuç insandan müteşekkil görüntüsü vermektedir.

Değişimin gerekli olup olmadığ bir yana, kimin adına ve ne için değişimi gerçekleştirmek istedikleri bile çok açık değildir. Çoğunlukla entelektüel birikimden yoksun, hayalperest, macera peşinde koşan deliler gibi hareket etmektedirler. Devrimi nasıl gerçekleştireceklerini bilmedikleri gibi asıl önemli olan Çarlık düzenini yıktıktan sonra yerine ne koyacaklarını düşünmemiş olmalarıdır. Yani kafalarında sistemli, mantıklı, toplumsal kesimlerin çıkarlarına yönelik bir plan-proje henüz somutlaşmış değildir. Akıllarında sadece nefret ettikleri -neden nefret ettikleri de çok açık değildir- bu düzeni zorla, kargaşa yaratmak suretiyle sarsmak ve gürültülü bir biçimde yıkmak vardır. Duygularıyla hareket etmektedirler ve ayağı yere basmayan hayalci bir bakış açısına sahiptirler. Bunun yanında herhangi bir ahlaki-manevi bir değere sahip olmadıkları gibi, ahlak-din-kilise-aile düşmanıdırlar. Filmde devrimcilerin başını çeken ve en tehlikeli bir deli, bir psikopat olarak görülebilecek kişinin, babasına karşı son derece saygısız davranışları, onu bir şekilde polise tutuklattırmaya çalışması, kiliseye saldırması ve aralarındaki üyelerden birini gözünü kırpmadan öldürmek için herkesi ikna etmesi, yönetmenin devrimcilerin hiçbir etik değer taşımadığını seyirciye ispat etme çabasının bir ürünü olarak okunabilir.

Filmde, şiddet isteği, devrimcilerde psikolojik hastalık sayılacak düzeydedir. Şiddet, yok etmek isteği Robespierre ve arkadaşlarınınkini aratacak şekilde araçsal bir şey olmaktan çıkmış devrimcilerin birincil amacı haline gelmiştir ve görünüşte onların önünde buna engel olacak hiçbir değer yargısı-norm bulunmadığı için tehlike daha büyük hale gelmektedir.

Muhafazakârların ahlak ve dini normların insanların açgözlü-kötü doğasını sınırlayan, onu kontrol altına alan fonksiyonu doğrultusunda kilise-aile gibi geleneksel kurumların toplumsal istikrarını vurgulayan tutumuna ${ }^{32}$ atfen filmde Kilise, bu çılgınların önündeki son savunma hattı olarak sembolleştirilmektedir. Filmde, içinde azıcık da olsa insaniyetlik-iyilik bulunan her kişinin en azından Tanrı'ya inanıyor olduğunu belirtmesi ya da hiç olmazsa İsa ikonasının önüne bir mum koyup yakması bu anlamda geleneksel yapıya saldıran bu delilere karşı oluşturulacak son savunma hattının ancak din ve kilise örgütlenmesi üzerinden gerçekleştirilebileceği fikrini aşılamaktadır. Bu tema, tarihsel olarak Polonyada Katolik kilisesinin Alman ve Rus işgalleri esnasında “direniş”e verdiği politik ve örgütsel desteği akıllara getirmektedir.

Ancak yönetmenin Çarlık düzenine övgü dizdiği sanısına kapılmamalıdır. Yönetmen değişimin gerekliliği konusunda farklı düşünmemekle birlikte, ayrıştığı nokta bunun geçmişten ahlaki-zihinsel ve kurumsal köklü bir kopuştan ziyade, devamlılık içinde, toplumsal yapıyı sarsmadan, zamana yayılmış şekilde ağır bir evrim süreci içerisinde yapılması gerektiğidir. Filmde de ifade edildiği gibi, yönetmene göre, Ruslar, millet olarak ciddi tarihi bir fırsat ellerine geçirmişlerdi. Eğer, bahsedilen biçimde bir dönüşümü başarmış olsalardı, dünya (muhtemelen Doğu Avrupa ve özellikle kendi ülkesi Polonya) bambaşka bir hale bürünmüş olacaktı. Ancak Ruslar, bu büyük fırsatı saplandıkları hayalcilik-şiddet-yok etme-devrim sarmalında yitirmişler ve bir

32 Mollaer ve Öztürk, a.g.e., s. 55. 
anlamda dünyanın kaderinin başka bir yöne evirilmesine yol açmışlardır. Danton filminde gördüğümüz aydınlanma eleştirisi, burada aydınlanma mirasına sahip çıkan sosyalizm-komünizm ideolojilerine karşı yöneltilmiştir. Özellikle sosyalizmin insanları eşit hale getirme çabasına ciddi bir karşı çıkış söz konusudur. Filmde, evde toplanan devrimcilerden birinin -ki bu adam son derece çirkin-itici ve küstah bir üsluba sahip olarak daha en başından seyircide negatif bir etki yaratmaktadır- Wajda’nın adeta dalga geçercesine resmettiği şekilsel demokratik kurallar (toplantının esasına yönelik oylama) ve tüm ahmakça tavırlarının (bir türlü ne konuşacaklarına dair gündem üzerinde anlaşamamaları) ardından konuşmayı başarabilmesiyle birlikte açıkladığı devrimden sonra kurulacak toplum yapısı çok ilginçtir: Söz konusu kişinin "sınırsız özgürlükten yola çıktığım zaman vardığım nokta hep sınırsız kölelik oluyor" sözü ya da "insanları eşit kılmak için hepsini eğitimsiz, yeteneksiz hale getirmek gerekli çünkü yetenekliler her zaman daha fazla yükselmek için mücadele ediyorlar ve toplumdaki eşitliği bozucu etki yapıyorlar” sözleri Sosyalizmin özgürlük söylemlerine karşın teorik olarak ciddi sorunları olan ve sonuçta mutlak eşitlik nedeniyle "kölelikte eşitlik" (Cicero’nun dilini, Shakespeare'in kafasını koparmak lazım deyimiyle) halini alan bir tür baskı rejimi -Nazizm gibi- olduğu savını üretmektedir. Yine bu sözler, sosyalizmin gelişme, ilerleme, bolluk gibi pozitif söylemlerinin içini boşaltan ve ona kitle üzerinde bir tür yeni sınıf-zümre baskısı yaratan bir rejim görünümü vermektedir. Bu eleştiriler, sosyalizme karşı liberal ve muhafazakâr kesimlerin dile getirdiği eleştirilerle önemli benzerlikler taşımaktadır. Yönetmenin de bu eleştirilere destek verdiği film boyunca hissedilmektedir.

Bunun yanı sıra, Wajda, Rus devriminin katıksız bir halk devrimi, kitle devrimi ve onların çıkarlarına yönelik gerçekleştirildiği savı kadar devrimden sonra kurulan proletarya diktatörlüğü ile halkın iktidarı ele geçirdiği yönündeki görüşün de hatalı olduğunu izleyiciye film boyunca hissettirmektedir. Filmde, devrimcilerin, her türlü haksızlığı, sorunu kendi çıkarları için kullanmaya çalışması hatta ortada herhangi bir sorun yokken dahi suni biçimde karışıklık, kargaşa çıkarmaya çalışmaları ve bunun üzerinden kendilerine çıkar sağlama çabaları bu bağlamda okunabilmektedir. Filmde Çarlık rejimi valisinin devrimcilerden birine "henüz çok erken" demesine rağmen devrimcilerin işten atılan işçileri bir yandan kışkırtırken bir yandan da valiyi işçilere karşı daha sert davranması için yüreklendirmesi, devrimcilerin aslında bahsedildiği gibi toplumsal koşulların gereğini yerine getiren tarihsel görev yüklü kişiler olmak bir yana adi kışkırtıcılar, düzen bozucular olduklarını seyirciye hissettirmektedir. Basit bir ücret anlaşmazlığı gibi görülen ve dışarıdan kasıtlı bir müdahale olmasa çok kolaylıkla çözülebilecek bir olayda işçilerin dayak yemesi, onların kasıtlı olarak kışkırtılması ve bu arada tüm bölgedeki evlerin -ki bunların çoğu yoksul-işçi barınakları gibi gözükmektedir- yakılması aslında bir anlamda devrimcilerin kimin çıkarlarına yönelik mücadele ettiğini göstermekte ve tıpkı Danton filmindeki sokakta ekmek kuyruğunda bekleyen halsiz düşmüş kitleler gibi Rus halkının kimilerinin iktidar mücadelesi için kullanıldığına işaret etmektedir.

Gerçekte halkın ciddi sorunları vardır. Haksızlığa uğramaktadırlar fakat yönetmen özellikle bu haksızlığa sebep olan toplumsal sınıfın kim ya da kimlerden oluştuğunu 
göstermekten kaçınır, ancak devrim bu sorunların çaresi olmayacağı gibi, bahsettiği anlamda bir dönüşümü de gerçekleştiremeyecektir. Çarlık sistemini bambaşka bir formda yeniden üretecek, fedakâr köylü, sosyalizmde de hakkına kavuşamadığı gibi en ağır şekilde sömürülmeye devam edecektir. Eşitlik, refahta eşitlikten ziyade, yoksullukta, sömürülmekte eşitlik halini alacak ve yine toplumdaki bazı ayrıcalıklı kesimler varlığını koruyacaktır. "Çar” ölüp gidecek fakat yerine "Stalin” gelecektir. Tebaa olarak varlıklarını Çar’a sunan kitleler, bu sefer sosyalizmi dünyaya yaymak için savaşacak, çalışacak, ölecek, öldürecektir. Aslında biçimde çok şey değişmiş gözükse de, özünde her şey aynı kalacaktır.

Devrimciler, Tanrı'yı sevmedikleri için, insanları ve hiçbir şeyi sevmemektedirler. Shatov'un deyişiyle "sadece nefret etmeyi bilmektedirler". Rusya’nın ilerlemesini umursadıkları da yoktur çünkü Rusya eğer ilerlerse nefret edecekleri bir şeyin kalmamasından korkmaktadırlar. İnsanı sevmeyen kişilerin iyi bir amaç uğruna çalışması da mümkün değildir. İnsanı sevmek için Tanrı’yı sevmek ve ona yakın durmak gerekir. Burada yönetmen, sosyalizmin yumuşak karnı olarak gördüğü "dinsizliğe" ya da "ateizme" saldırmakta ve onu tam da bu nedenle sınırsız tiranlık olarak görebilmektedir.

Shatov'un tam da bu noktada uyanıp, gerçeklerin farkına varması ilgi çekicidir. Eski bir devrimci olan Shatov, bir anlamda gidişatı görmüş ve yıkıma giden bu süreçte Tanri’ya sığınarak bu gruptan kurtulmak yolunu seçmiştir. O da işçidir ve ezilmektedir. Hatta gerektiğinde arkadaşları için sopa yemeyi bile göze almaktadır. Haksızlığa karşı mücadele etmenin gerekliliğine inanmaktadır fakat buna karşın Tanrı'ya inanmakta, inançlı, ahlaklı bir insan olarak yaşamak istemektedir.

Tanrıya inanmayışın sonunun ya devrimciler gibi delilik ya da intihar olduğu savı ateizm kadar nihilizme yönelik muhafazakâr karşı duruşun bir örneğini sunmaktadır. Kullanıldığını anlayan ve kaybettiği Tanrı'sını ve kısa zaman sonra dönen karısının doğum yapmasıyla aile saadetini ve ebedi mutluluğu keşfeden Shatov, aslında yönetmen tarafından "ideal” bir birey olarak izleyicinin karşısına çıkarılmaktadır. Devrim gibi, büyük ve beceremeyeceği bir şeyden vazgeçip, haksızlıklar için Tanrı’ya sığınmak ve mutluluğu maddi şeylerde (para-iktidar vb.) aramak yerine manevi şeylerde (aile-kadın-bebek vb.) aramak yönetmenin gözünde en doğru yol olarak görülmektedir. Yaşanan sıkıntıların kaynağının en temelinde Tanrıdan, geleneksel değerlerden (aile-ahlak-din vb.) uzaklaşmak olduğu ve insanlığın kurtuluşu, Ömer Şerif'in son sahnede İncil'den yaptığı alıntıdan anlaşılacağı üzere "içine giren cinden kurtulup İsa’nın dizleri dibine çökmekte” bulabileceği anafikri seyirciye aktarılmaktadir.

\section{Katyn}

2007 yılında çekilen Katyn filmi ${ }^{33}$, yönetmen için ayrı bir özellik taşımaktadır. Film, 1939'da Rusya ve Almanya arasinda imzalanan ve tarihe Ribbentrop-Molotov Ant-

33 Katyn, (2007), Andrzej Wajda, Polonya yapımı, http://www.imdb.com/title/tt0879843, Erişim tarihi: 04.05.2012. 
laşması olarak geçen antlaşmanın gizli bir maddesi gereği Rusların Polonya’yı işgal etmesini ve Polonyalı yaklaşık 22000 askerin Almanya ile işbirliği yaptıkları gerekçesiyle infaz edilip toplu mezarlara gömülmesini konu edinmektedir. Andrzej Wajda’nın babası da bu katliamda öldürülen askerler arasında yer almaktadır. Ayrıca bu katliamın uzun süre saklanması, infaz edilenlerin kimliklerinin açıklanmaması ve Almanlarla Rusların uzun yıllar boyunca bu katliam için birbirilerini suçlayıp durmaları Polonya tarihine acı bir hatıra olarak geçmesine yol açmıştır. Bu acıları çeken ve yıllar boyunca bir gün eve döneceği umuduyla babasını bekleyen yönetmenin kendisi için de bu film, acılarla bir tür yüzleşme niteliği taşımaktadır. ${ }^{34}$ Uzun süre kim tarafından yapıldığı belirlenemeyen katliam, SSCB’nin Polonya üzerindeki fiili hâkimiyetini sürdürdüğü yıllarda resmen Almanlar tarafından yapılmış bir olay olarak kabul edilmiş ve aksi fikirler büyük ölçüde devlet tarafından sansüre takılmıştır. ${ }^{35}$

En nihayetinde SSCB’nin reformcu devlet başkanı Mihail Gorbaçov tarafından kabul edilen ve 1990 yılında resmen sorumluluğu üzerine alınan katliamla ilgili resmi belgeler Rusya Federasyonu devlet başkanı Boris Yeltsin tarafından Polonya devlet başkanı Lech Walesa'ya 1992 yılında teslim edilmiştir. Bu belgelerle birlikte katliamın Rusya tarafından Stalin’in emriyle sistemli biçimde gerçekleştirildiği ortaya çıkmış ve yıllar boyunca katliamın Almanlar tarafından gerçekleştirildiğine yönelik resmi propaganda inandırıcılığını tamamen yitirmiştir.

Film, yönetmenin kendi aile acılarıyla özel bir yüzleşme olduğu kadar, filmin çekildiği yıl itibariyle hem o dönemi yaşayanlar için bir anıları tazeleme hem de SSCB dönemini, Soğuk Savaş’ı yaşamayan genç Polonyalı kuşak için bir ulusal hafıza yaratma amacı taşımaktadır. Film, 1990 sonrası Wajda filmleri gibi SSCB ve komünizmin yarattığ 1 devlet sansüründen kurtulmuş olmanın verdiği rahatlıkla daha keskin eleştirileri doğrudan sergilemektedir. Önceki filmlerde görülen dolaylı eleştiriler (Danton'da Jakobenlere-aydınlanmaya, Ecinniler'de devrimci gruplara ve diğer birçok filmde Almanlara-Nazizm’e), bu filmde doğrudan adresini bulmuş gibi gözükmektedir. Sovyet sonrası Doğu Avrupa'nın politik ve ekonomik krizinin 2000'lerle birlikte Avrupa Birliği perspektifi içerisinde, en azından şimdilik, çözülmüş görünmesi Wajda’nın eski Sovyet dönemini çok daha rahat eleştirmesine olanak tanımaktadır. Katyn filminde, 1990 öncesi filmlerinde görülen iyi işçi-kötü devrimci, iyi halk-kötü yönetici karşıtlığı bambaşka bir bağlama oturmuş ve halk artık Polonya milleti vasfını kazanarak milliyetçi bir şekle bürünmüştür. Bunu, Sovyet sonrası yükselişe geçen komünizm ve Rus-Slav karşıtlığı üzerinden şekillenen milliyetçi bir yeniden uyanış-bilinç kazanma hareketinin ${ }^{36}$ Wajda'nın sinemasına uzantıları olarak görmek mümkündür.

Filmde, Katyn katliamı ana ekseni oluştursa da, ana hikâye Katyn katliamında ölenlerden ziyade onları bekleyen anneler, kardeşler, çocuklar etrafında şekillenmektedir. Birbirinden farklı birçok hikâye, katliamda birilerini kaybeden kişilerin yaşadık-

34 Mark H. Teeter, “Wajda’s Katyn: the healing truth”, http://rbth.co.uk/articles/2010/04/28/wajdas_katyn_the_ healing_truth.html, Erişim tarihi: 05.05.2012.

35 Willam Woods, Poland: Phoenix in the East (London: Penguin Books, 1972), s. 12-14.

36 Gerard Delanty, Avrupa'nın İcadı, çev., Hüsamettin İnaç (Ankara: Adres Yayınları, 2004), s. 188. 
ları kayıp, üzüntü, hınç, intikam gibi duygular üzerinden ortaklaşmakta ve birbirini beslemektedir. Bu haliyle Wajda'nın, eski dönemin meta anlatılar şeklinde özellikle savaş filmlerinde belli başlı karakterler üzerinden şekillenen büyük hikâyeler yerine, birbirinden kısmen bağımsız küçük hikâyelerle, kahraman sayılamayacak, sıradan insanların öykülerini anlatarak bir anlamda modern sinema anlatımından post modern sinema anlatımına geçiş yaptığı söylenebilir. Üstelik bu filmde eski filmlerinde görülmeye alışık olunan taraflar-saflar, iyi-kötü, düşman-dost gibi siyah-beyaz şeklinde ayrımlar o denli net değildir. Yönetmen, Soğuk Savaş’n bitimi ardından dağılan safların, ittifakların yarattığı kafa karışıklığından önemli ölçüde nasibini almış gözükmektedir. Ama en nihayetinde yönetmen, kendisinin de sıklıkla bahsettiği üzere, filmlerini bir Polonyalı olarak çekmekte ve en başından beri Polonya'nın kendi hikâyesini anlatmak ve anlattığı, ele aldığı konulara Polonya merkezli bakmayı tercih etmektedir.

Bu kapsamda Katyn filminde Polonya tam da Nazi Almanyası ile Sovyet Rusyası gibi iki dev-süper güç arasında kalmış, ikisinden de darbe yiyen, ezilmiş bir ülke görünümünde ortaya çıkmaktadır. Bir tür şansızlık, kadersizlik, Tanrı’nın takdiri olarak okunabilecek bu durum, bir yanıyla Polonyảnın acılar çekmesine yol açsa da bir yanıyla da onun yeniden onurlu bir "millet" olarak silkinip ayağa kalkması ve bağımsızlığ bağımsız bir millet olarak hayal eden, gören daha önceki benzer filmlerine göre milli olana vurgu bu filmde daha belirgin bir tona sahiptir. ${ }^{37}$

Komünizm ve Nazizm arasında kalan Polonya halkı için (buna yönetmen de dâhildir) iki ideoloji arasında ciddi bir fark yoktur. İkisi de Aydınlanma düşüncesini kendisine miras aldığını belirtmekte, toplumu belli bir teorik model çerçevesinde gerekirse zorla değiştirmeyi amaçlamakta ve bambaşka bir toplum hayaline ulaşmak niyetindedirler. İkisi de söylemsel düzeyde haksızlığı yok edip, eşit ve adil bir toplum düzeni kuracağını vaat etmekte ve bu kapsamda her türlü geleneğe, toplumsal alışkanlıklara, yaşam tarzlarına, kurumlara karşı baştan düşmanca bir tavır oluşturmaktadırlar. Her ikisi de Polonya'yı kendi etki alanlarını genişletmek adına işgal etmekte bir sakınca görmemişler ve her iki işgal de binlerce ölü, yaralı ve bombalanmış şehirlerle, çöken günlük yaşamla sonuçlanmıştır. Önce Naziler, üstün Alman ırkına yaşam alanı (Lebensraumpolitik) sağlamak için Polonya’yı işgal etmiş, ardından Ruslar komünizm ütopyası adına işçilerin haklarını korumak, eşit, sömürüsüz bir dünya yaratmak amacıyla önce Almanları yenmiş ardından Polonyảyı fiilen işgal edip, kukla bir hükümet yaratmışlardır. ${ }^{38}$ Birisi, diğerinden daha iyi ya da kötü değildir. Her ikisi de Polonya bağımsızlığının, gelişmesinin, Polonya vatandaşlarının hak ve özgürlüklerinin önünde büyük engeller olagelmişlerdir. Öyle ki “işçinin vatanı yoktur” sözüyle Polonya milletinin milli uyanışını engellemek istemişler, milliyetçiliği kötü bir düşünce olarak göstermeye çalışmışlardır. Filmde bu anlamda bir istasyondaki Polonya’nın kırmızı-beyaz bayrağının, bir Rus askeri tarafından yırtılıp kırmızı

37 Peter Zupnik, "What was the nationality of the stuffed teddy bear", http://www.salon.eu.sk/article. php?article=1044-what-was-the-nationality-of-the-stuffed-teddy-bear, Erişim tarihi: 05.05.2012.

38 Oral Sander, Siyasi Tarih 1918-1994 (Ankara: İmge, 2007), s. 123-126, 208. 
kısmının komünizmin rengi olarak yeniden asılırken beyaz kısmının aynı asker tarafından küstahça bir tavırla ayağına bağlanması bu çerçevede okunabilir.

Nazizm ve komünizmin bilimsellik iddiası da filmde eleştirilmektedir. Krakow Üniversitesi’nin Nazi yöneticilerinden habersiz, öğrenci alımı yapması ya da sınav düzenlemesi gibi uygulamaları nedeniyle kapatılması ve tüm bilim adamlarının toplama kamplarına sürgün edilmesi gibi, komünistlerin Katyn ormanlarında öldürdükleri 22000 Polonyalının çoğunun okumuş, entelektüel birikime sahip, Polonya’yı yeniden ayağa kaldıracak aydınlar olması ve bu insanların sadece savaş suçlusu olmalarının ötesinde Polonya’yı tekrar diriltecek insani gücü oluşturması hem komünistlerin hem Nazilerin ülkeyi bu insan kaynağından yoksun birakarak daha kolay yönetilebilir hale getirme çabası olarak görülür. ${ }^{39}$ Çünkü yönetmenin bakışına göre bu ideolojiler milletleri cehalet, çaresizlik ve umutsuzluk içinde birakarak, kendi aç1larından daha rahat idare edilebilir hale getirdikleri için Polonya’ya aydınlık değil koyu bir karanlık getirmişlerdir.

Katyn katliamının sorumluğunu yıllarca kabul etmeyen ve sözde bilimsel araştırmacılardan müteşekkil komisyonlarca sorumluluğu karşı tarafa atanlar aslında aynı iddialarla sahneye çıkmaktadırlar. Yönetmenin ince bir espriyle ele aldığ 1 bu mevzu aslında Polonyalıların hem Nazilere hem komünistlere sadece "düşman" olarak baktıklarını göstermektedir. Filmde, öldürülen askerlerin kafalarının arkasına birer kurşun sıkıldığı ve bunun Nazilerce komünistlerin infaz biçimi, komünistlere göre Nazilerin klasik infaz biçimi olduğu iddiası bu açıdan trajikomik bir ayrıntı olarak ele alınmaktadir.

Filmde söz konusu iki ideolojinin insana atfettiği büyük değer de bir şekilde eleştirilmektedir. Muhafazakârlar bireyi toplumsal olanın içinde tek başına büyük öneme sahip bir parça olarak görmemelerine karşın, insanın tanrısal bir yönü olması sebebiyle ona değer atfetmekten de geri durmamaktadırlar. ${ }^{40}$ Bununla birlikte, insana bunca önem atfeden iki ideolojinin insanları savaşlarda, devrimlerde, yıkımlarda değersizleştirip birer paçavra haline getirdiği eleştirisi -Danton filminde giyotinden düşen kelleler, Ecinniler filminde yanan, boğazı kesilen insanlar ve Katyn'de infaz edilen askerler- filmin sonunda ormanın içinde yüzü seçilemeyen kişilerin komünistler tarafından değersiz birer yaratıkmışçasına katledilişleri ve kazılan çukurlara üst üste atılmalarının yürek burkan görüntüsü üzerinden somutlaştırılmaktadır.

Filmde öne çıkan mesele, Polonya’nın kurtuluşudur. Bu şüphe yok ki antikomünist-milliyetçi ve Katolik değerlere bağlı bir kurtuluş olacaktır. Polonya’nın kurtuluşuna olan umut koma halindeki bir hastanın yaşayacağına duyulan umuttan daha kuvvetli değildir ama herkes Polonya’nın yeniden ayağa kalkacağı, bağımsız olacağ güne belli belirsiz bir inanç beslemektedir. Yaşlılar, uzun süredir savaşın içinde mahvolan hayatlarına, kana, toza, bomba parçalarına bulanan anılarına bakarak o günü göremeyeceklerini düşünmekte ve son bir direniş konusunda çok da hevesli gözük-

39 Anne Applebaum, “A Movie that Matters”, http://www.nybooks.com/articles/archives/2008/feb/14/a-moviethat-matters, Erişim tarihi: 05.05.2012.

40 Kekes, a.g.e., s. 36-37. 
memektedirler. Orta yaşlılar, daha iyimser olmakla birlikte birincil sorunları olan "yaşamaya devam etmek" meselesi ile daha alakadar gözükmektedirler. En azından yakın gelecekte böyle bir umut belirmediği sürece bütün mesailerini savaştan arta kalanları toplayıp, tamir etmekle, sorumluluklarını taşıdıkları insanları yaşatmakla ve yeniden normale dönmekle meşgul olmak isteğindedirler. Fakat en gençleri, kanlarının verdiği enerji ile kaybettikleri babalarının, kardeşlerinin, arkadaşlarının hala sıcak olan acılarının verdiği hınç ve öfkeyle hemen karşılık vermek, savaşmak, silahlı bir direniş örgütlemek niyetindedirler. Yaşlılar mesele ile ilgilenecek takati kendilerinde bulamazken orta kuşak insanlar gençleri hayalcilikle, kendilerini gereksiz yere ateşe atmak, öldürmekle suçlamaktadırlar. Asıl yapılması gereken silahlı direniş değil, Polonya’yı, her yönüyle çöken bu ülkeyi yeniden güçlü hale getirmek için çalışmak olmalıdır. Okumak, eğitim görmek, kendi kültürünü, dilini yaşatmak, kiliseye gitmek bile bu yolda bir tür mücadele sayılabilir. Çünkü Polonya’nın önce Katyn ormanlarında ya da diğer cephelerde kaybettiği yetişmiş insan gücünü telafi etmesi, yeniden üretmesi gereklidir. Bu da ancak komünistlere karşı değil onlarla beraber, onlarla uzlaşarak, uyumlaşarak, onların otoritesini kabul ederek ve ancak zaman içinde gerçekleştirilebilir bir durumu ifade etmektedir.

Kimin vatansever, kimin işbirlikçi, kimin düşman, kimin dost, kimin Polonya'yı daha çok sevdiği, kimin onun zararına çalıştığı, kimin vatansever, kimin hain olduğu filmde pek açık değildir. Yönetmen postmodern kavramlardan, tarafları muğlaklaştıran havasından açıkça esinlenmiş olarak bu tür bir ayrıma gitmek yerine farklı hikâyeleri, farklı bakışları bir arada ama Polonya zemininde sunarak -bir tane de olsa iyi bir kızıl komünist askerin yer alması ama Polonyalı, gururlu subay karısının bu iyi niyetli Rus'un her şeye rağmen yardımını kabul etmemesi gibi- izleyiciye bunlardan istediğine inanabileceğini göstermiştir.

Hain-vatansever, direnişçi-işbirlikçi gibi ayrımlar farklı ülkelerde belli tarihsel zaman dilimlerinde oluşmuştur. Wajda, bu ikilemi gerçekten taraf tutmadan, birini kötü addedip, ötekini müdafaa etmeye dönüştürmeden gerçekçi bir biçimde ele almaktadır. Bunun yanı sıra olayları daha politik bir küreden daha duygusal bir alana taşımakta ve filmi acılar, kayıplar, kaybolan anılar, yıkılan aileler gibi daha toplumsal meseleler üzerinden geliştirerek bir yanıyla insani yönü ağır basan bir film çekmiştir.

\section{Sonuç}

Polonya sinemasının özellikle İkinci Dünya Savaşı sonrasında yetiştirdiği en büyük sinemacılardan biri olan Andrzej Wajda, Polonya tarihi açısından büyük kırılmalara sahne olan Alman İşgali, İkinci Dünya Savaşı, Sovyet İşgali ve SSCB’nin yıkılışı gibi olayların tümüne tanıklık etmiştir. Seksen altı yaşına gelen ve Polonya’nın bir gün bağımsız, özgür olacağına şahitlik edeceğine fazla ihtimal vermeyen Wajda, şimdiden Polonya’nın, tarihinin, kültürünün ve sinemasının gelişiminde ayrıcalıklı bir yer edinmiştir.

Nazizme ve Komünizme karşı her zaman mesafeli ve eleştirel bir duruş sergileyen Wajda yaptığı filmlerle en baskıcı dönemlerde bile bu tutumundan vazgeçmemiş ve sinemasal anlamda Polonya’nın kendi kültürüne dayanan, milli ve özgün bir sinema 
geleneği oluşturmak çabası içerisinde olmuştur. Aydınlanmacı değerlere ve bu değerleri miras aldığına inandığı, özgürlükçü, eşitlikçi olduğuna inanmadığı totaliter rejimlere karşı Polonya halkının öz değerlerini, milli kültürünü ve bu kimliğin-kültürün ayrılmaz bir parçası olarak gördügü aile değerlerini, kiliseyi ve ahlaki ilkeleri ön plana çıkarmaya gayret etmiştir. Bu anlamda, başta Danton, Ecinniler ve Katyn filmleri olmak üzere yaptığı filmlerde Polonya milliyetçisi, muhafazakâr bir tutum sergilemiştir.

\section{Kaynakça}

Applebaum, Anne, "A Movie that Matters", http://www.nybooks.com/articles/ archives/2008/feb/14/a-movie-that-matters, Erişim tarihi: 05.05.2012.

Borden, Daniel, Florian Duijsens, Thomas Gilbert ve Adele Smith. Başvuru Kitapları: Film. Çev., Yasin Kara, İstanbul: NTV Yayınları, 2011.

Delanty, Gerard. Avrupa'nın İcadı. Çev., Hüsamettin İnaç. Ankara: Adres Yayınları, 2004.

Dubiel, Helmut, Yeni Muhafazakârlık Nedir? Çev., Erol Özbek. İstanbul: İletişim Yayınları, 1998.

Dunn, Charles W., Woodard, J. David. American Conservatism From Burke to Bush: An Introduction. London: Madison Books, 1990.

Hearnshaw, F. J. C. Conservatism in England. New York: Howard Fertig Inc., 1967.

Flam, Helena. Mosaic of Fear: Poland and East Germany before 1989. New York: Columbia University Press, 1998.

Girvin, Brian. The Right in the Twentieth Century: Conservatism and Democracy. London: Pinter Publishers, 1994.

Heywood, Andrew. Political Ideologies. New York: Palgrave, 1998.

Hobsbawm, Eric. Kısa Yirminci Yüzyıl (1914-1991). Çev., Yavuz Alogan. İstanbul: Sarmal Yayınları, 2003.

Karpinski, Maciel. The Theatre of Andrzej Wajda. Çev., Christina Paul. Cambridge: Cambridge University Press, 1989.

Kekes, John. A Case For Conservatism. New York: Cornell University Press, 1998.

Kristol, Irvin. Autobiography of An Idea: Neo Conservatism, Selected Essays. New York: The Free Press, 1995.

Mazower, Mark. Karanlık Kıta. Çev., Mehmet Moralı. İstanbul: Bilgi Üniversitesi Yayınları, 2003.

Mollaer, Frrat ve Öztürk, Armağan. "Muhafazakâr İdeoloji ve Rasyonalite". İ. Siyasal Bilgiler Dergisi. 35 (2006): 49-72.

Özipek, Bekir Berat. Muhafazakârlık: Akıl, Toplum, Siyaset. Ankara: Kadim Yayınları, 2005.

Pillbeam, Bruce. Conservatism in Crisis? Anglo American Conservative İdeology after the Cold War. New York: Palgrave Macmillian, 2003.

Poland (1944-1964). Warsaw: Poland Publishing House, 1964. 
Sander, Oral, Siyasi Tarih 1918-1994. Ankara: İmge Kitabevi, 2007.

Szporer, Mieczyslaw. “Andrzej Wajda's Reign of Terror: Danton's Polish Ambiance”. Film Quarterly. 37/2 (1984): 27-34.

Tanilli, Server. Fransız Devriminden Portreler. İstanbul: Adam Yayınları, 2003.

Teeter, Mark H., “Wajda's Katyn: the healing truth”, http://rbth.co.uk/ articles/2010/04/28/wajdas_katyn_the_healing_truth.html, Erişim tarihi: 05.05.2012.

Wajda, Andrzej. Sinema ve Ben. Çev., Füsun Ant. İstanbul: Afa Yayınları, 1993.

Woods, William. Poland: Phoenix in the East. London: Penguin Books, 1972.

Yılmaz, Aytekin. Çă̆daş Siyasal Akımlar. Ankara: Vadi Yayınları, 2003.

Zupnik, Peter, "What was the Nationality of the Stuffed Teddy Bear", http://www. salon.eu.sk/article.php?article=1044-what-was-the-nationality-of-the-stuffedteddy-bear, Erişim tarihi: 05.05.2012.

\section{Andrzej Wajda ile ilgili internet siteleri}

Andrzej Wajda'nın biyografisi: http://culture.pl/en/artist/andrzej-wajda.

Andrzej Wajda'nın filmografisi: http://worldcat.org.

Andrzej Wajda’nın filmografisi: http://www.imdb.com.

Andrzej Wajda'nın resmi sitesi: http://www.wajda.pl/en/default.html

Andrzej Wajda'nın tüm eserleri: http://www.filmreference.com/film/88/AndrzejWajda.html. 


\title{
A Nationalist-Conservative Director in Polish Cinema After the Second World War: Andrzej Wajda
}

\author{
SÜLEYMAN SIDAL
}

Abstract: This study attempts to review the political view of Andrzej Wajda who is one of the best known film director of Poland cinema. I analyze Wajda's films, Danton, Les Possedes and Katyn in order to understand his nationalist and conservative attitude. First, I briefly evaluate the meaning of nationalism and conservatism, and then consider his life story and filmography. Yet, I mainly concentrate on those films Danton, Les Possedes and Katyn in the context of the relationship between nationalism and conservatism.

Basic argument of the article is that Andrzej Wajda has a nationalist and conservative political tendency which stands against both Nazism and Socialism, and the Enlightenment ideas which to some extend rooted in these ideologies.

Keywords: Andrzej Wajda, Polish cinema, nationalism, conservatism, enlightenment values. 